\title{
The Rural Hinterland of the Visigothic Capitals of Toledo and Reccopolis, between the Years 4OO-8OOCE
}

\author{
Javier Martínez Jiménez
}

When I first approached the topic of this volume, ${ }^{1}$ I felt that the recent archaeological finds of Spain deserved attention from the broader (i.e., English speaking) academic world, as these finds were not often discussed in wider studies of early medieval and late antique rural transitions. This has thankfully improved since then. ${ }^{2}$ However, by presenting a case study from the Iberian Peninsula using the rich archaeological records, this paper aims to offer a comparative viewpoint from the "Far West" and to put it in its context with the eastern examples presented in this volume.

The province of Madrid has numerous rural sites dating to the late Roman and Visigothic period which have been recently excavated and published, but very few of these places seem to continue archaeologically into the Umayyad period. By contrast, the evolution of the main towns of this area (Complutum and Reccopolis, and to a lesser extent, Toledo) is fairly well-known throughout this period. Strikingly, these two developments have hardly been studied together as part of the same historical processes.

1 This paper was written in 2010, and since then, some of the sites presented in this paper have been further published, and their context within the territory of Toledo in the transition between the Visigothic and Umayyad periods has also been discussed in print. The most up-to-date publication on this area and topic would be the proceedings of the "AD 711" conference held at the Regional Archaeological Museum of Madrid in Alcalá de Henares (Luis A. García Moreno, ed., 711: Arqueología e Historia entre dos mundos, Zona Arqueológica 15 (Alcalá de Henares: Museo Arqueológico Regional, 2011)). I have, furthermore, included part of these conclusions in more recent publications: Javier Martínez Jiménez, and Carlos Tejerizo García, "Central Places in the Post-Roman Mediterranean: Regional Models for the Iberian Peninsula," Jorunal of Mediterranean Archaeology 28, no. 1 (2015): 105-132 and Javier Martínez Jiménez, Isaac Sastre de Diego, and Carlos Tejerizo García, The Iberian Peninsula Between 300 and 850: An Archaeological Perspective, Late Antique and Early Medieval Iberia 6 (Amsterdam: Amsterdam University Press, 2018), but I decided to leave the text of this chapter closer to the original version.

2 Jamie Wood and Martínez Javier Jiménez, "New Directions in the Study of Visigothic Spain," History Compass 14, no. 1 (2016): 29-38. 
In this paper I will present a synthetic overview of the available material, showing how the rural landscape of this region was closely linked to the evolution of its towns, and how the creation and destruction of the Visigothic kingdom caused, first, the expansion and, later, the decline of its capitals and their rural network. Likewise, these political changes are closely linked to the evolution of the elites, who not only controlled the rural territory, but also played an important role in the politics of the Visigothic kingdom.

In short, this paper will show how the Roman rural villa system collapsed by the end of the fifth century, how it was restructured on a different pattern of villages during the Gothic period, and then how this ceased to exist once the Visigothic system and its seats of power were substituted by new Umayyad centres.

The Region of Toledo and Reccopolis

This paper will focus on the central part of the Peninsula: the hinterland of the Visigothic capital of Toledo which roughly matches the modern province of Madrid, but also including part of the neighbouring provinces of Toledo and Guadalajara. It is there that the impact of the successive processes of state formation (the Visigothic and the Umayyad) on the rural landscape can be seen most clearly.

The province of Madrid (figure 3.1) is a triangular region, roughly covering 8,ooo square kilometres and geographically divided into three areas: the mountains (la sierra) which engulf the north-west edge of the triangle ranging between 800 and 2500 miles above sea level, the meadows (las vegas) constituting the fertile lands around the rivers Tajo, Manzanares, Jarama, Guadarrama and Henares (with their tributaries) expanding down to Toledo in the south, and, finally, the plains (la campiña) consisting of the region towards the East into the province of Guadalajara and the region of Reccopolis.

The rural sites discussed in this paper are located mostly in the meadows and at the main rivers, but a significant number of sites is located at the feet of the mountain ranges. The location next to the rivers provided direct access to water for consumption and irrigation and facilitated transport, as the main roads of the period either followed these rivers from north to south or linked the different valleys from east to west. ${ }^{3}$

3 Carlos Caballero Casado, "Caminos sobre caminos: un recorrido por las rutas visigodas en Madrid," in La investigación arqueológica de la época visigoda en la Comunidad de Madrid, 


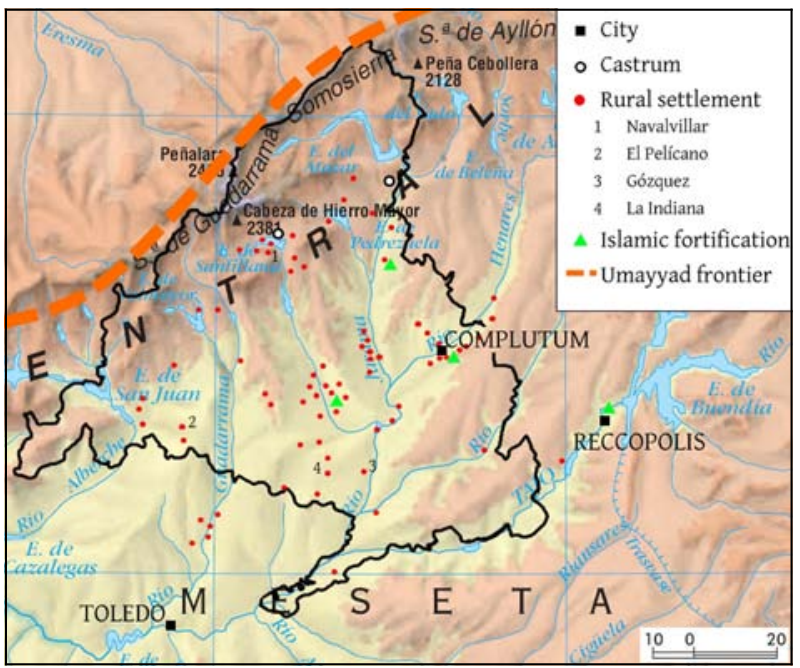

FIGURE 3.1 Map of Madrid and the surrounding provinces, showing the distribution of late Antique settlements, highlighting those mentioned in the text MAP MADE BY THE AUTHOR

There are too many excavated sites to make a detailed account of each of them here, but they can be clustered into three groups, each of which will be discussed in detail: 4

1. dispersed nuclei or isolated farms, linked to small burial sites and which tended to be short-lived (e.g. La Huelga, Fuente de la Mora, Cacera del Valle);

2. settlements with evidence for the existence of a village community, with a longer duration in time, some of them linked to high status rural settlements, like monasteries (e.g., Gózquez, Navalvillar, El Pelícano, Congosto);

3. and fortified hilltops, which were walled enclosures close to key roads or mountain passes (the sites of Patones and Cancho del Confesionario).

ed. Jorge Morín de Pablos, Zona Arqueológica 8 (Alcalá de Henares: Museo Arqueológico Regional, 2007), 92-102.

4 Alfonso Vigil-Escalera Girado, "El modelo de poblamiento rural en la meseta y algunas cuestiones de visibilidad arqueológica," in Gallia e Hispania en el contexto de la presencia 'germánica' (ss. V-VII): balance y perspectivas, eds. Jorge López Quiroga, Artemio Manuel Martínez Tejeda and Jorge Morín de Pablos, British Archaeological Reports International Series 1534 (Oxford: Archaeopress, 2006), 89-91. 
All these have varying chronologies, but they can all be characterised as late antique $^{5}$ inasmuch as they show a different settlement distribution pattern from the ones we know from the Roman and later medieval periods.

One note of caution concerning the archaeological material is, however, in order. Most sites have been identified through rescue archaeology and thus have a serious sampling problem. In other words, the location of the known sites may not be representative. We only know those sites that have been excavated and reported in the areas where in recent years have seen constant construction. That is why most of the sites are located in the continuously developing southern 'industrial belt' of Madrid (see figure 3.1). While we obviously cannot discuss sites we have not found, we should be careful not to consider the sites discussed here as the only existing ones or even as being representative.

\section{The Collapse of the Roman System of Town and Country}

The administrative and political changes imposed during the Tetrarchy (293$313 \mathrm{CE}$ ) triggered a series of long-term transformations which changed the way elites interacted with their urban and rural environments and the relationship between cities and their territories. ${ }^{6}$ These changes were aimed at increasing the centralisation of the administration at all levels at the expense of local governance. The centralisation of taxes limited the amount city councils could invest in monuments and maintenance, while the decline of traditional magistracies deterred the curiales from investing private funds into public munificence. Cities which preserved their administrative status continued to indulge in a Roman-style urban life, but secondary and tertiary nuclei failed to do so. The urban nuclei in our study fall in the second category. ${ }^{7}$

5 The Spanish literature refers to these more usually as 'early Medieval', but I believe that as they belong to a Historical process which begins as a response to the political end of Rome but within a Christian Roman cultural context, should be still be seen as late antique (cf. Martínez Jiménez, Sastre de Diego and Tejerizo García, Iberian Peninsula, ch. 1).

6 Wolfgang Liebeschuetz, "The End of the Ancient City," in The City in Late Antiquity, ed. John Rich, (London/New York: Routledge, 1992), 7-15. Bryan Ward-Perkins, The Fall of Rome and the End of Civilisation (Oxford: Oxford University Press, 2005); Peter Heather, The Fall of the Roman Empire: A New History of Rome and the Barbarians (Oxford: Oxford University Press, 2005).

7 Summarised in Javier Martínez Jiménez, "Crisis or Crises? The End of Roman Towns in Iberia Between the Late Roman and the Early Umayyad Periods," in Tough Times: The Archaeology of Crisis and Recovery. Proceedings of the GAO Annual Conferences 2010 and 2011, eds. Elsbeth van der Wilt and Javier Martínez Jiménez, British Archaeological Reports International Series 2478 (Oxford: Archaeopress, 2013), 77-9o. 
In Toledo and Complutum traditional Roman townscapes transformed. These changes started in the fourth century, but they became noticeable during the fifth. The streets and public buildings like fora and basilicas were encroached upon or pulled down. ${ }^{8}$ Public services such as water supplies, baths or spectacula ceased to function. ${ }^{9}$ In Complutum the transformation of the Roman landscape went even further, as it developed into a poli-nucleated town with the old centre being depopulated in favour of newly emerging suburbs stretching along the main road. The new main foci of the town were not the abandoned forum or the basilica, but the martyrs' shrine of Saints Justus and Pastor and the small settlement around the old villa of El Val. ${ }^{10}$ The case of Toledo is more difficult to assess, because we know so little about the early Roman town. It is clear, however, that he upper town continued to function during the fourth century, while an incipient Christianisation is clearly detectable in the lower town during the fifth. ${ }^{11}$

During the Roman period the cities and their rural hinterland had become thoroughly interconnected mostly through a network of villa estates. Although the villa-based economy survived and continued into the fourth century, a bifurcation in the evolution of villa estates is already noticeable by the midfourth century. While some were slowly turning into simpler production sites, with the luxury residence ceasing to be a focal element, others experienced an opposite change, turning into lavish rural palaces. Examples of the latter development in the area under study are the palaces of Carranque and Noheda. ${ }^{12}$ This evolution might reflect an amalgamation of various smaller estates into

8 Sebastián Rascón Marqués and Ana Lucía Sánchez Montes, "Urbanismo de la ciudad de Complutum los siglos VI-VII," in Recópolis y la ciudad en la época visigoda, ed. Lauro Olmo Enciso, Zona Arqueológica 9 (Alcalá de Henares: Museo Arqueológico Regional, 2008), 247,254 .

9 For Complutum: Sebastián Rascón Marqués, "La ciudad de Complutum en la tardoantigüedad: restauración y renovación," in Acta Antiqua Complutensia I: Complutim y las ciudades hispanas en la antigüedad tardía, eds. Luis García Moreno and Sebastián Rascón Marqués (Alcalá de Henares: Universidad de Alcalá, 1999), 237, 241. For Toledo, cf. Javier Martínez Jiménez, "Aqueducts and Water Supply in the Towns of post-Roman Spain AD 400-1000" (PhD diss., Oxford University, 2014), 49.

10 Rascón Marqués and Sánchez Montes, “Urbanismo," 255.

11 Josep Maria Gurt Esparraguera and Pilar Diarte Blasco, "La basílica de santa Leocadia y el final de uso del circo romano de Toledo: una nueva interpretación," Zephyrus 69 (2012): 149-163.

12 Miguel Ángel Valero Tévar, La villa romana de Noheda: la sala triclinar y los mosaicos (PhD diss., University of Castilla-La Mancha, 2015); Dimas Fernández-Galiano, Carranque: Esplendor de la Hispania de Teodosio (Barcelona: Museu d'Arqueologia de Catalunya, 2001). 
several larger ones and the changing relationship between urban elites and their rural estates. After the Barbarian invasions the gradual disappearance of the Roman imperial apparatus prompted the collapse of the rural system based on cash-crops and large villa estates in the fifth century. ${ }^{13}$

The dismantling of these villas is clearly visible in the archaeological record: villas lost their original functionality, were reused as multi-family dwellings, production areas, or even for burials. New buildings were built in timber and pisé (rather than in masonry) and sunken features (Grunbenhäuser) became widespread. ${ }^{14}$ Besides these changes a process of Christianisation of the material culture is obvious. ${ }^{15}$ These changes underline how the villa changed from an elite residence to a full-on productive settlement inhabited by a new Christianised population continuing to live on site.

The villas of La Indiana (Pinto), El Val (Alcalá de Henares), Tinto Juan de la Cruz (Pinto), Prado de los Galápagos (Alcobendas) and Valdetorres del Jarama are the ones in which these transformations are most clearly visible. ${ }^{16}$ Whereas some villa sites were abandoned in the course of the fifth century, like the villa of Valdetorres, the vast majority slowly transformed into other types of rural settlements after the elite residence had been abandoned. ${ }^{17}$ This is the case, for instance, in the villa of El Prado de los Galápagos, on the fertile banks of the Jarama river. Once the villa collapsed in the course of the fifth century, the site was sub-divided into a new small settlement located 200 meter away from the old villa and a minor reoccupation of the pars urbana. ${ }^{18}$ At the site of El

13 Martínez Jiménez, Sastre de Diego and Tejerizo García, Iberian Peninsula, ch. 3.

14 Alfonso Vigil-Escalera Girado, "Cabañas de época visigoda: evidencias arqueológicas del sur de Madrid: Tipología, elementos de datación y discusión," Archivo Español de Arqueología 73 (2000): 223-252; Carlos Tejerizo García, "Estructuras de fondo rehundido altomedievales en la Península Ibérica," Munibe 65 (2014): 215-237.

15 Cf. Miguel Ángel García García, "Sarcófagos romanos decorados del siglo Iv en el territorio andaluz: enfoques y problemática vigente," Spal 21 (2012): 183-193; Jorge López Quiroga, “¿Dónde vivían los germanos? Poblamiento, hábitat y mundo funerario en el occidente europeo entre los ss. V y viII. Balance historiográfico, problemas y perspectivas desde el centro del reino 'godo' de Toledo," in La investigación arqueológica de la época visigoda en la Comunidad de Madrid, ed. Jorge Morín de Pablos, Zona Arqueológica 8 (Alcalá de Henares: Museo Arqueológico Regional, 2007), 318-319.

16 Jorge Morín de Pablos et al., "Repertorio de yacimientos de época visigoda en la Comunidad de Madrid," in La investigación arqueológica de la época visigoda en la Comunidad de Madrid, ed. Jorge Morín de Pablos, Zona Arqueológica 8 (Alcalá de Henares: Museo Arqueológico Regional, 2007), 56.

17 Vigil-Escalera Girado, "El modelo de poblamiento," 95.

18 Vicente M. Sánchez Sánchez-Moreno, Lorenzo Galindo San José and Rebeca Recio Martín, "Trabajos arqueológicos en el yacimiento 'El Prado de los Galápagos,", in La investigación arqueológica de la época visigoda en la Comunidad de Madrid, ed. Jorge Morín de Pablos, 


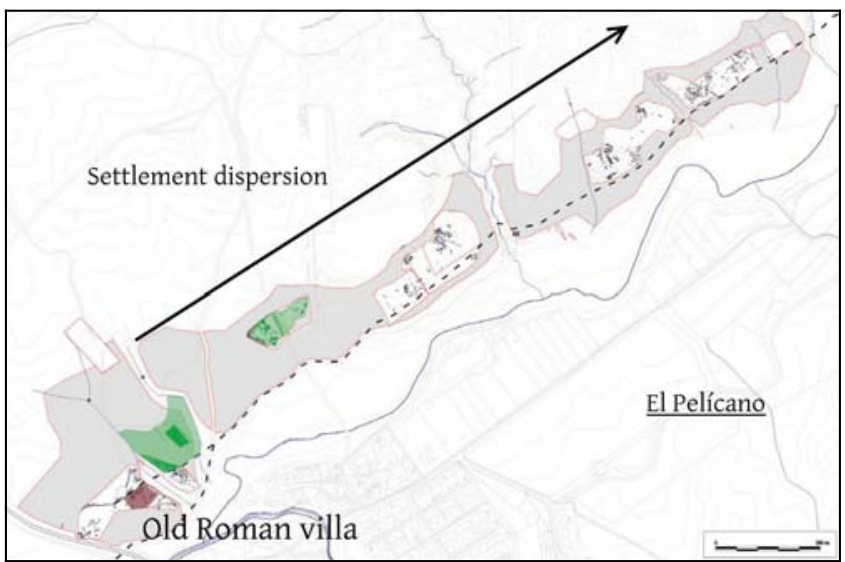

FIGURE 3.2 Plan of the excavations at the site of El Pelícano (Arroyomolinos), in its sixth-seventh century phase, showing the disperse settlement along the river away from the original Roman settlement, marking out the land plots and the communal spaces FROM VIGIL-ESCALERA, "LAS ALDEAS ALTOMEDIEVALES," FIGURE 11

Pelícano (Arroyomolinos), the old villa was abandoned in the 430 s. The rich owner [?] was buried in a large mausoleum and the tenants resettled in a new nucleated village close to the old villa (figure 3.2$) \cdot{ }^{19}$ The first-century villa of La Indiana (Pinto) was transformed in the fifth century to house several families in timber and pisé houses. ${ }^{20}$

Most of these villas were apparently abandoned and then reoccupied or slowly modified and transformed into a completely different settlement. In a few cases, however, villas seem to have been abandoned after an episode of violence. This is the case for the villas of El Val and Tinto Juan de la Cruz, but it is very difficult to establish a link with the Barbarian invasions in the region as hardly anything is known about these. ${ }^{21}$

Zona Arqueológica 8 (Alcalá de Henares: Museo Arqueológico Regional, 2007), 447-469; López Quiroga, “¿Dónde vivían los germanos?” 339-341.

19 Alfonso Vigil-Escalera, "Las aldeas altomedievales madrileñas y su proceso formativo," in The Archaeology of Early Medieval Villages in Europe, ed. Juan Antonio Quirós Castillo, Documentos de Arqueología e Historia 1 (Bilbao: Euskal Herriko Unibersitatea, 2009), 321324 .

20 Alfonso Vigil-Escalera Girado, "La Indiana (Pinto, Madrid): estructuras de habitación, almacenamiento, hidráulicas y sepulcrales de los ss. VI-IX en la Marca Media," in XXIV Congreso Nacional de Arqueología 5 (1999): 205-207.

21 Morín de Pablos et al., "Repertorio de yacimientos," 56. 
The fifth century marked a period in which the late Roman political and economic model, developed after the Tetrarchy, came to an end. The resulting instability and lack of strong political authority caused new patterns to emerge substituting the Roman architectural and visual manifestations.

The Emergence of the Village: Freedom in a Power Vacuum?

As explained above, starting in the fifth century the villa as a settlement type and economic unit was substituted by radically different villages. This transformation process took place between the mid-fifth and the mid-sixth century and it appears to be a wide-spread phenomenon all across Europe. ${ }^{22}$ The dissolution of the Roman state and its tax-system brought an end to the rural economy model based on the colonate liberating the peasants as described by Hydatius. ${ }^{23}$ This may well be a reason behind the process of village formation. At the same time no strong political authority, either Roman or Germanic, was able to control the central areas of the Iberian Peninsula resulting in a long period of power vacuum. The earliest archaeologically identifiable village is that of Congosto (Rivas) dated to the second half of the fifth century. ${ }^{24}$ Other sites, such as at Gózquez (San Martín de la Vega) and Navalvillar (Colmenar Viejo) similarly emerged at this moment of apparent power vacuum. ${ }^{25}$

22 For the chronology, see e.g. Juan Antonio Quirós Castillo, "Early Medieval Villages in Spain in the Light of European Experience: New Approaches in Peasant Archaeology," in The Archaeology or Early Medieval Villages in Europe, ed. Juan Antonio Quirós Castillo, Documentos de Arqueología e Historia 1 (Bilbao: Euskal Herriko Unibersitatea, 20o9), 13-28. For the geographical spread, see Helena Hamerow, Early Medieval Settlements: The Archaeology of Rural Communities in Northwest Europe, 400-900 (Oxford: Oxford University Press, 2002).

23 Boudewijn Sirks, "Reconsidering the Roman Colonate," Zeitschrift der Savigny-Stiftung für Rechtsgeschichte: Romanistische Abteilung 110, no. 1 (1993): 331-369. Hydatius "Chronica subita," in The Chronicle of Hydatius and the Consularia Constantinopolitana, ed. Richard Burgess (Oxford: Clarendon, 1993), 40.

24 Vigil-Escalera, "El modelo de poblamiento," 96; Vigil-Escalera, "Aldeas altomedievales," 334 .

25 Vigil-Escalera, "Aldeas altomedievales," 329; Concepción Concepción Abad Castro, "El poblado de Navalvillar (Colmenar Viejo)," in La investigación arqueológica de la época visigoda en la Comunidad de Madrid, ed. Jorge Morín de Pablos, Zona Arqueológica 8 (Alcalá de Henares: Museo Arqueológico Regional, 2007), 396; Fernando Colmenarejo García and Cristina Rovira Duque, "Los yacimientos arqueológicos de Colmenar Viejo durante la Antigüedad Tardía," in La investigación arqueológica de la época visigoda en la Comunidad de Madrid, ed. Jorge Morín de Pablos, Zona Arqueológica 8 (Alcalá de Henares: Museo Arqueológico Regional, 2007), 378. 


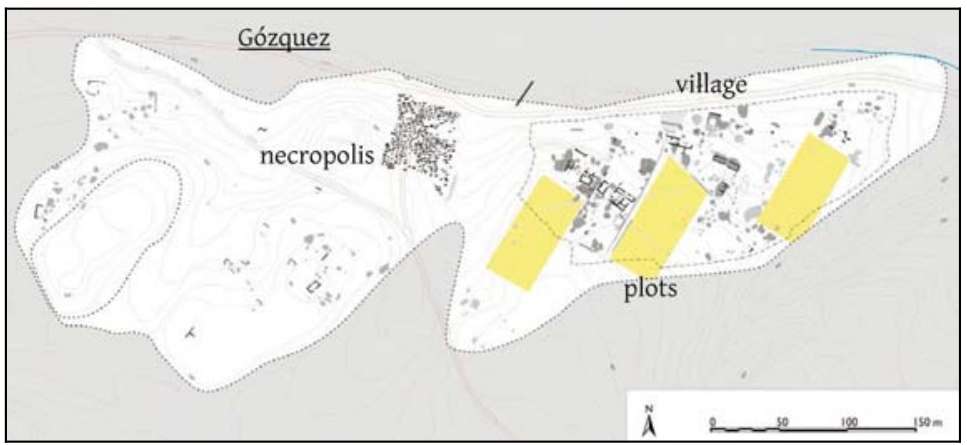

FIGURE 3.3 Plan of the site of Gózquez de Arriba (San Martín de la Vega), showing the core settlement in the east and the necropolis to the west FROM Vigil-esCALERA, "LAS ALDEAS ALtomedieVAles," FigURE 15

During this first formative stage villages developed the structural, social, and economic characteristics that would define them for the rest of the Visigothic period and beyond. We have already seen that villa structures were dismantled and new constructions in reused and perishable materials became the norm. The villages' economy changed from monoculture and cash crops to a more diversified production of food and goods. This was especially the case where the import of staple foods and daily objects became unreliable. Social life was characterised by the presence of peasant communities articulated through communal spaces, family plots or allotments, and by new ways of defining social hierarchies. ${ }^{26}$ These characteristics are noticeable in villages grown out of villas and in newly settled ones.

Smaller plots were probably the result of the subdivision of old Roman ones. This is visible at the site of El Pelícano. But the presence of small plots is also characteristic of newly established villages such as Gózquez (San Martín de la Vega). ${ }^{27}$ Communal features consist of necropoleis, olive presses, grazing grounds, silos and, from the seventh century onwards, churches. ${ }^{28}$ Gózquez, built ex novo ca. 530, is probably the best excavated example, as it has communal oil presses and necropoleis (figure 3.3). ${ }^{29}$

26 Chris Wickham, Framing the Early Middle Ages: Europe and the Mediterranean: 400-800 (Oxford: Oxford university Press, 2005), 436-441.

27 Vigil-Escalera, "El modelo de poblamiento," 94.

28 For the churches, see Vigil-Escalera, "El modelo de poblamiento," 90-91, although these do not appear inside the village area, but in other, nearby rural contexts.

29 Vigil-Escalera, "Aldeas altomedievales," 329-331. 
The presence of these communal spaces and smaller plots does not, however, mean that these were egalitarian peasant communities. Evident traces of social differentiation confirm this. The village communities seem to have been linked through horizontal networks of patronage without any relation to the previous Roman rural elites. This suggests some degree of self-administration. It is possible, however, that the local Roman aristocracies still could exercise some degree of control over the village communities as well. During periods of crisis or transformation like this transition from the fifth to the sixth century, social hierarchies are not properly defined with a high degree of hierarchical competition. Those ending up on top may well have been the descendants of the old Roman rural elite. As their position was contested by new contenders amongst whom possibly newly arrived Visigoths, they found ways to re-establish and redefine their position in a changed society. The emerging elite based its position solely on personal prestige visible in burial practices, similar to what we see in rural Gaul and Germany. ${ }^{30}$

Indicating rank through prestige is the "big-man" model of anthropological literature. In this society prestige was partly demonstrated by the conspicuous destruction of wealth by including grave goods. In the few necropoleis that we have for this area, such as Daganzo and Gózquez, we find small knives, weapons, and other small objects that characterise the "Duero Necropoleis". Rather than ethnic indicators of the new Germanic settlers, these objects functioned as markers of status referring to the militarised Roman elites, who from the fourth century onwards wore these items as status symbols. ${ }^{31}$

These new village communities developed against the background of a collapsed villa economic system and the disappearance of traditional means of Roman elite representation. The new economic and social structures reflected a landscape without a strong state to exercise direct control, but with internal differentiation. This situation would be further accentuated once the Visigothic kingdom extended its urban networks of patronage and authority into the rural countryside.

30 Guy Halsall, Barbarian Migrations and the Roman West, 376-568, Cambridge Medieval Textbooks (Cambridge: Cambridge University Press, 2007), 125-131, 342-346, 352-357.

31 Ángel Fuentes Domínguez, La Necrópolis tardorromana de Albalate de las Nogueras (Cuenca) y el problema de las denominadas 'Necrópolis del Duero', Arqueología Conquense 10 (Cuenca: Diputación Provincial de Cuenca, 1989); Carlos Tejerizo García, "Ethnicity in Early Middle Age Cemeteries: The Case of the "Visigothic" Burials," Arqueología y Territorio Medieval 18 (2011): 29-43. 


\section{$4 \quad$ Village Networks in the Visigothic System}

By the mid-sixth century the Visigoths had already shifted their main focus of action to the Iberian Peninsula. Liuvigild (r. 568-586) began a series of state reforms, a process known by modern historians as aemulatio imperii. ${ }^{32}$ It included a reorganisation of the fiscal system, the coinage and the territorial administration. These changes continued trends that already began in the 55os according to the historical sources, but only at this stage do they became archaeologically evident. Liuvigild moved his capital to Toledo. The large twenty hectare palatine suburb which has been recently excavated there, must be connected to the praetorium suburbanum mentioned in the sources. This palatine complex was a physical projection of the new Visigothic state apparatus. ${ }^{33} \mathrm{He}$ also created a new city in $578 \mathrm{CE}$, Reccopolis (figure 3.4), named after his son, which included a large public building identified as a palace, a basilica, walls, suburbs and an aqueduct. ${ }^{34}$ It was linked to a new province called Celtiberia probably to substitute the declining Complutum or the longdisappeared Ercavica as regional centre. Celtiberia's limit might well have been somewhere in the modern-day province of Madrid. This new city was a royal centre of fiscal and territorial administration, as can be concluded from the presence of a mint. ${ }^{35}$ This process of urban renewal affected many other sites, not only in the core of the kingdom, but also in areas further away. In

32 Evangelos Chrysos, "The Empire, the gentes and the regna," in Regna and Gentes: The Relationship between Late Antique and Early Medieval Peoples and Kingdoms in the Transformation of the Roman World, eds. Hans-Werner Goetz, Jörg Jarnut and Walter Pohl (Brill: Leiden, 2003), 13-20; Edward Thompson, Los Godos en España (Madrid: Alianza, 2007), 78-83, 107-112.

33 Lauro Olmo Enciso, "La Vega Baja en época visigoda: una investigación arqueológica en construcción," in La Vega Baja de Toledo, ed. María del Mar Gallego García (Toledo: Toletum Visigodo, 20o9), 69-94; Lauro Olmo Enciso, "Ciudad y Estado en época Visigoda: la construcción de un nuevo paisaje urbano," in Espacios urbanos en el Occidente Mediterráneo ss. VI-VIII, eds. Antonio García, Ricardo Izquierdo, Lauro Olmo and Diego Perís (Toledo: Toletum Visigodo, 2010), 87-112; Ricardo Izquierdo Benito, "La Urbs Regia," in Hispania Gothorum: San Ildefonso y el reino visigodo de Toledo, ed. Rafael García Serrano (Toledo: Toledo Visigodo, 2007), 143-159.

34 Olmo Enciso, "Recópolis," 40-63. For the aqueduct, Javier Martínez Jiménez, "A Preliminary Study of the Aqueduct of Reccopolis," Oxford Journal of Archaeology 34, no. 3 (2015): 301-320.

35 John of Biclar, "Chronica a. DLXVII-DXC," in Chronica Minora, v. 2, Monumenta Germaniae Historica Auctores Antiquissimi v. 11, ed. Theodor Mommsen (Berlin: Preussiche Akademie 1934, 207-220), s.a. 578; Morín de Pablos et al., "Repertorio de yacimientos," 62; Olmo Enciso, "Recópolis." 


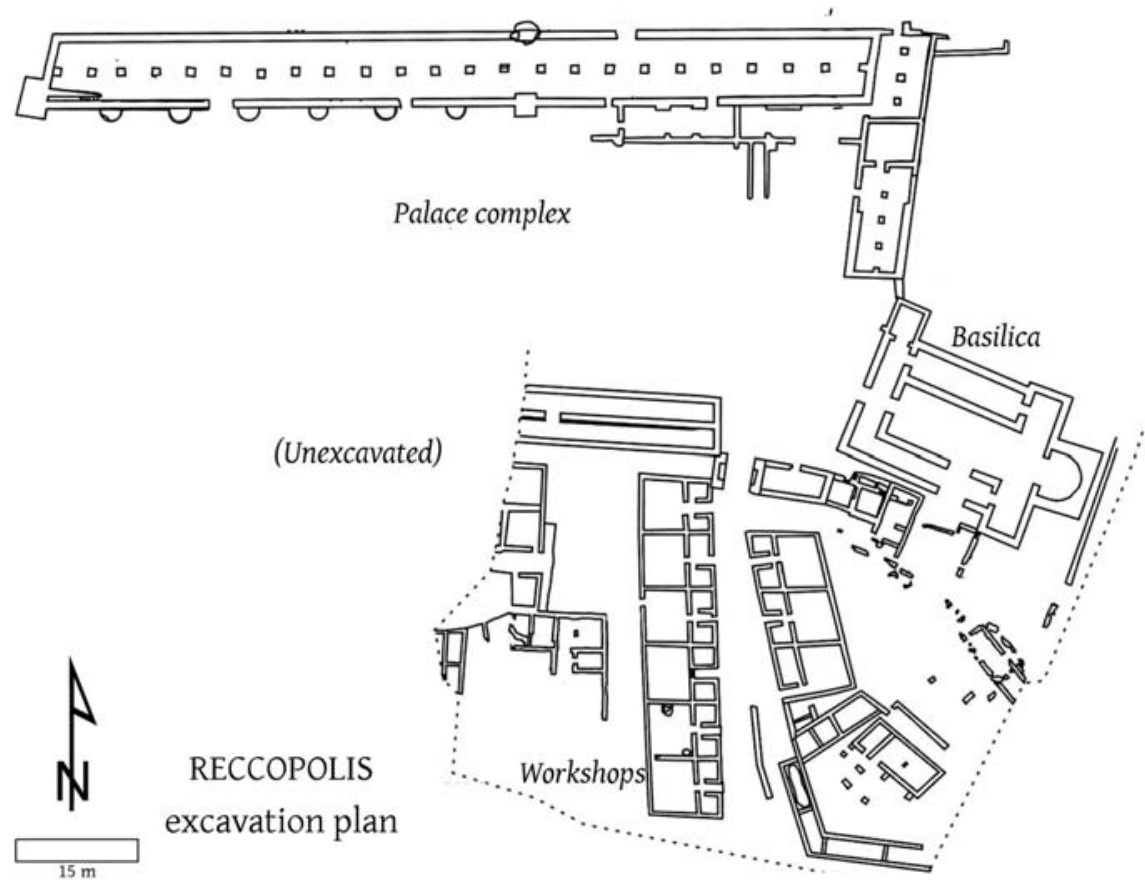

FIGURE 3.4 Plan of the excavations of Reccopolis

FROM OLMO ENCISO, "RECÓPOLIS," FIGURE 3

Barcelona and Valencia new buildings arose linked to a new urban administration. These trends can also be observed in the newly founded bishopric and fortified town of Eio. ${ }^{36}$

36 Martínez Jiménez and Tejerizo García, "Central Places."

On Barcelona: Julia Beltrán de Heredia Bercero, "Continuity and Change in the Urban Topography: Archaeological Evidence of the North-East Quadrant of the City," in From Barcino to Barchinona (first to seventh centuries): The Archaeological Remains of the Plaça del Rei in Barcelona, ed. Julia Beltrán de Heredia Bercero (Barcelona: Museu d'Història de la Ciutat, 2002), 96-111. By the same author, "Barcino durante la antigüedad tardía," in Recópolis y la ciudad en la época visigoda, ed. Lauro Olmo Enciso, Zona Arqueológica 9 (Alcalá de Henares: Museo Arqueológico Regional, 2008), 274-291. On Valencia: Albert Ribera Lacomba, "La ciudad de Valencia durante el periodo visigodo," in Recópolis y la ciudad en la época visigoda, ed. Lauro Olmo Enciso, Zona Arqueológica 9 (Alcalá de Henares: Museo Arqueológico Regional, 2008), 303-320; Albert Ribera Lacomba and Miquel Rosselló Mesquida, "La ciudad de Valentia en época visigoda," in Los orígenes del cristianismo en Valencia y su entorno, ed. Lacomba Albert Ribera (Valencia: Ajuntament de València, 2000), 151-164. On Eio, see Sonia Gutiérrez Lloret, and Julia Sarabia Bautista, "The Episcopal Complex of Eio-El Tolmo de Minateda (Hellín, Albacete, Spain): Archi- 
The implementation of these state structures required the Visigothic military elites, the royal court, the Roman landed aristocrats, the curial elites and the Church to cooperate. A new service elite arose as a consequence, which soon included the rural village elites. ${ }^{37}$ As a result the newly emerging village landscape developed into an interconnected hierarchical network of settlements. Similar processes are known to have taken place elsewhere in Europe, where sites such as Gasselte, Mucking, Flögeln and Vorbasse arose in connection to similar processes of state formation. ${ }^{38}$

As a result of this process of state formation the region of Madrid had become the hinterland of the capitals and the core of the kingdom. It is here that the extent of Visigothic territorial control can be observed best. It is obvious in the archaeological record in various ways. The first archaeological indicator of the extension of Visigothic control over the rural territory of Madrid is the intensified settlement network. This period coincides with the highest known number of villages. ${ }^{39}$ Other centres of elite control emerged at this moment as well. The re-settlement of hillforts (castra) in the sierra can be interpreted as the extension of a Visigothic territorial network. This network was based on central nodes controlling the villages and surrounding areas. The cities of Reccopolis, Toledo and to a lesser extent, Complutum, executed control over the villages and other minor settlements in the lowlands and the meadows, whereas the hillforts controlled the villages of the sierra. The two known castra of the region, Patones (or Pontón de la Oliva) and Cancho del Confesionario were located on hill tops from which the significant number of settlements located in the immediate surroundings were kept in check. From Patones it is even possible to see the immediate surroundings of Complutum. Patones is located at the end of the road which links the valley of the Jarama river with

tecture and Spatial Organization," Hortus Artium Medievalium 19 (2013): 262-30o; Javier Martínez Jiménez, "Water Supply in the Visigothic Urban Foundations of Eio (El Tolmo de Minateda) and Reccopolis," in New Cities in Late Antiquity. Documents and Archaeology, ed. Efthymios Rizos, Bibliotéque de l'Antiquité Tardive 35 (Turnhout: Brepols, 2017), 233-246.

37 Aitor Fernández Delgado, Javier Martínez Jiménez and Carlos Tejerizo García, "New and Old Elites in the Visigothic Kingdom (550-650AD)," in Tough Times: The Archaeology of Crisis and Recovery. Proceedings of the GAO Annual Conferences 2010 and 2011, eds. Elsbeth van der Wilt and Javier Martínez Jiménez, British Archaeological Reports International Series 2478 (Oxford: Archaeopress, 2013), 161-170.

38 Helena Hamerow, "Settlement Mobility and the 'Middle Saxon Shift': Rural Settlements and Settlement Patterns in Anglo-Saxon England," Anglo-Saxon England 20 (1991): 1-18; Harm Tjalling Waterbolk and Otto Harsema, "Medieval Farmsteads in Gasselte," Palaeohistoria 21 (1979): 228-265.

Vigil-Escalera, "Aldeas altomedievales," 337. 
Complutum and the rural sites of Talamanca, Cerro de Las Losas or La Cabeza can be found very nearby. ${ }^{40}$ Next to Cancho del Confesionario we find the sites of Navalvillar (figure 3.5) and La Vega. ${ }^{41}$

Even if these castra were not elite dwellings in the old Roman fashion, they can certainly be linked to the new administrative and territorial elite. A distinctive material culture, more diverse than that of most lowland village sites including imported goods characterised the elite culture of the sites. ${ }^{42}$ These castra in turn depended on the towns in a territory characterised by central sites with subordinated villages. ${ }^{43}$ This is a clear contrast with the Roman pattern of extensive urban territories largely controlled by villas. In the Visigothic model the countryside was still monitored by aristocrats, but they no longer resided on rural residences as the Romans did, or at least these have not yet been found. Control of the countryside was thus organised between the cities, the self-administrating village communities, and new local rural elites, who emerged during the period of power vacuum of the fifth century and who were based in the castra, probably with the support of the central administration in the cities. ${ }^{44}$

Imbedded within this network, albeit starting at a later period, but independent from the hierarchy, we find monasteries. Monasteries are a late antique rural innovation, although they do not appear in the Spanish archaeological record before the sixth century. ${ }^{45}$ Two monastic sites are known, both near Toledo: Melque and Guarrazar. Melque, renowned for its still-standing church, was built in the late Visigothic period and remained in use into the eighth century when the church was renovated. The monastery is connected to various irrigation canals and dams, which underline its role as a rural productive community. ${ }^{46}$ Guarrazar, also of late Visigothic origin, is better known for its

40 Vigil-Escalera, "El modelo de poblamiento," 92; Morín de Pablos et al., "Repertorio de yacimientos," 64 .

41 Colmenarejo García and Rovira Duque, "Yacimientos arqueológicos," 38o.

42 These sites are linked to elite works and elite control of the territory, but there is no hint at all of elite residence in the old Roman fashion in these sites; Quirós Castillo, "Early Medieval Villages."

43 Vigil-Escalera, "Aldeas altomedievales," 318-319.

44 Cf Martínez Jiménez and Tejerizo García, "Central Places," 86-88.

45 Francisco Moreno Martín, La arquitectura monástica hispana entre la Tardoantigüedad y la alta Edad Media, British Archaeological Reports International Series 2287 (Oxford: Archaeopress, 2011).

46 Luis Caballero Zoreda, "El conjunto monástico de Santa María del Melque (Toledo) siglos VIII-IX," in Monjes y monasterios hispanos en la Alta Edad, eds. José Ángel García de Cortázar and Ramón Teja Ruiz de Aguirre (Toledo: Fundación Santa María La Real, Centro de Estudios del Románico, 2006), 99-146. 


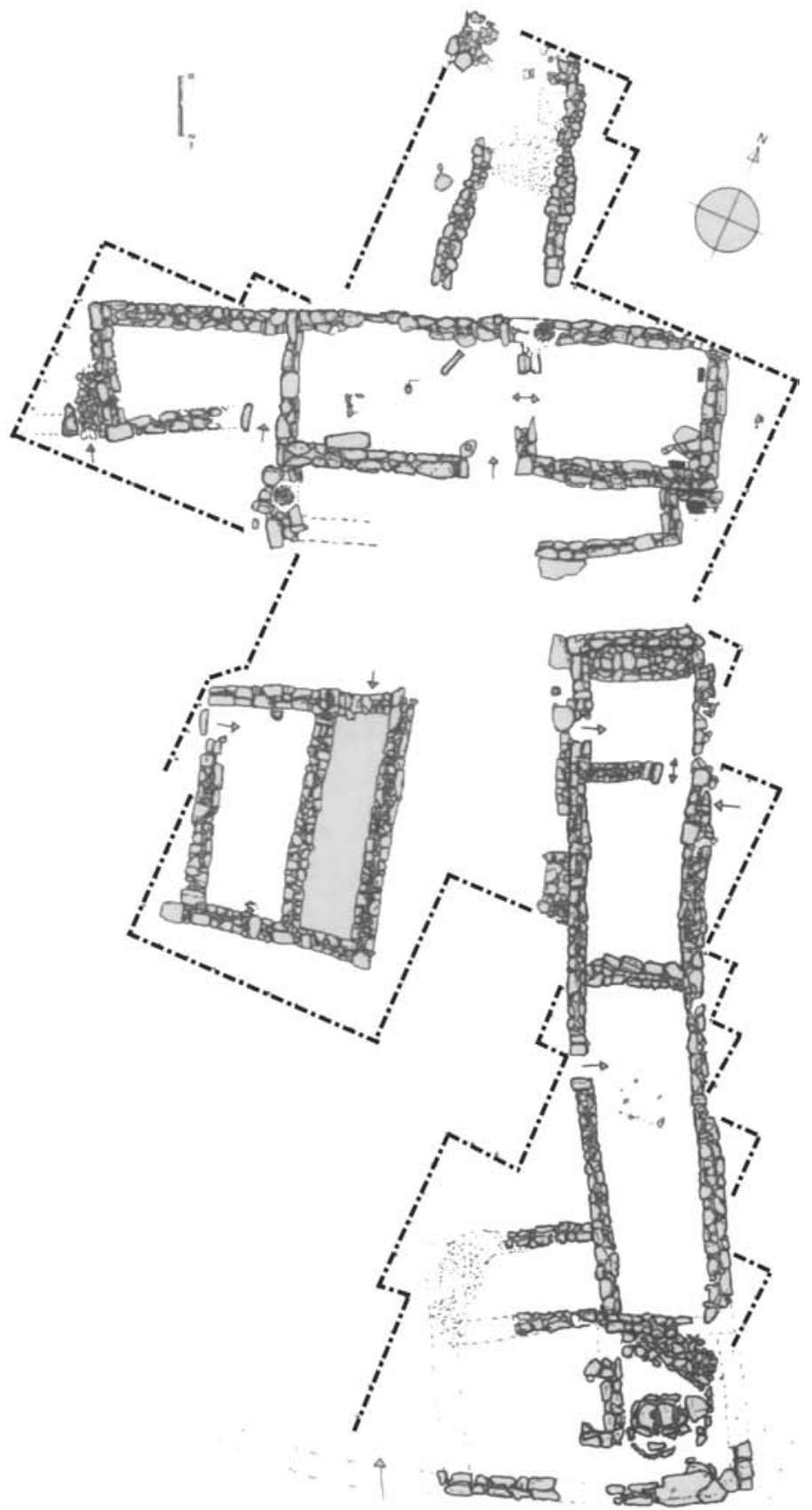

FIGURE 3.5 Plan of the site of Navalvillar, in Colmenar Viejo From abad CASTRo, "El poblado DE NAVAlVillar," FIGURE 1 
treasure: a collection of gold crowns dedicated by the Visigothic kings, and allegedly hidden during the 711 invasion. Recent excavations have unearthed various structures related to the monastery, which has been linked to direct royal patronage ${ }^{47}$ The monasteries constituted an expansion of urban authority into the countryside. On the one hand the monasteries were often founded by lay aristocrats, perhaps even the monarchy, but on the other they underline the power of the Church concerning territory control.

This direct involvement of the Visigothic state apparatus in the hinterland of Toledo inevitably coincided with the reintroduction of taxes collected in kind. An increase in the number of silos can be linked to the establishment of decentralised taxation structures at the village level. The settlements of the lowlands seem to have focused on the production of cereals, vines and olives, continuing the Roman model, to supply their own necessities and the Visigothic capitals of Toledo and Reccopolis. The presence of large numbers of grain silos in most of the sites of the vega may point to large-scale production. In sites like La Indiana up to 44 silos are found from the Gothic period. ${ }^{48}$ In other sites like Gózquez we find olive presses and there are very large storage areas at the village of El Pelícano. ${ }^{49}$ The Middle Guadarrama Survey has revealed that all surveyed sites were linked to grain production. ${ }^{50}$ Since all these sites were, moreover, located on the road to Toledo, it is probable that they were directly supplying the capital. Other settlements which emerged from old villas, like El Prado de los Galápagos, could also have been part of this network in the vega. Most of the settlements of the sierra seem to be more closely linked to animal husbandry than to agriculture, although crops were still being cultivated there as well. Animal pens and animal bones are far more common on these sites than on those of the lowlands, and silos, although present, are not as numerous. ${ }^{51}$ The village of Navalvillar is probably the best example. This settlement seems to have been organised around a communal space or street, in which there are several storage areas for grain, but also a byre and animal pens.

47 Juan Manuel Rojas Rodríguez-Malo, "Guarrazar: Arqueología y nuevos recursos: un proyecto con un siglo y medio de retraso," in VI Jornadas de Cultura Visigoda, 31-52 (Guadamur: Ayuntamiento de Guadamur, 2014).

48 Vigil-Escalera, "La Indiana," 207-208.

49 Vigil-Escalera, "Aldeas altomedievales," 326, 331.

50 Santiago Rodríguez and Carlos Barrio, "Poblamiento tardorromano en el valle medio del río Guadarrama (Toledo)," Bolskan 20 (2003): 269-271.

51 López Quiroga, “¿Dónde vivían los germanos?” 342-343; Abad Castro, “Navalvillar," 391; María del Mar Alfaro Arregui and Asunción Martín Bañón, "La Vega: un modelo de asentamiento rural visigodo en la provincial de Madrid," in La investigación arqueológica de la 
A fragmentary inscription on slate at Gózquez can also be used as a potential indicator of taxation. ${ }^{52}$ These slate inscriptions, characteristic of the mountain areas of the central Peninsula (especially the site of Lancha de Trigo in Ávila), are very varied. Some of them include writing exercises, others contain short notes but a great deal are considered to be fiscal registers. ${ }^{53}$

This integration of the village communities into the administrative and patronage networks of the Visigothic urban elite appears to have prompted a certain degree of economic diversification and economic interconnection beyond taxes. The widespread distribution of roof tiles in these rural areas, for example at Navalvillar, Gózquez and Prado de los Galápagos, can be linked to one regional centre of tile-production at Prado Viejo. ${ }^{54}$ The widespread distribution of wheel-made pottery, with matching typologies, across sites in the sierra and the vega (Navalvillar, Prado de los Galápagos, La Vega, La Indiana, Gózquez, etc.) also indicates a regional circulation of commodities which was not produced separately on each site, but came from a common source. ${ }^{55}$ Furthermore, all the widespread typologies have been dated to the second half of the sixth century, which would indicate that a period of stability began when the Visigothic kingdom was established in Toledo allowing for the distribution of these wares around the region. ${ }^{56}$ These typologies do not seem to match those found in urban contexts such those of Reccopolis and Toledo, which suggests the presence of distinct rural workshops. ${ }^{57}$

época visigoda en la Comunidad de Madrid, ed. Jorge Morín de Pablos, Zona Arqueológica 8 (Alcalá de Henares: Museo Arqueológico Regional, 2007), 409.

$5^{2}$ Juan Antonio Quirós and Alfonso Vigil-Escalera Girado, "Networks of Peasant Villages Between Toledo and Velegia Alabense, Northwestern Spain (v-xth Centuries)," Archaeologia Medievale 33 (2006): 79-128.

53 Iñaki Martín Viso, "Tributación y escenarios locales en el centro de la Península Ibérica: algunas hipótesis a partir del análisis de las pizarras visigodas," Antiquité Tardive 14 (2006): 263-29o.

54 For the distribution of rooftiles throughout the region, see Ward-Perkins, Fall of Rome, 109. And for specific sites, Abad Castro, "Navalvillar," 392. Vigil-Escalera, "Aldeas altomedievales," 332.

55 Alfaro Arregui and Martín Bañón, "La Vega," 414-417. This is slow wheel, i.e., hand-thrown wheel pottery. The fast wheel (foot-powered wheel) was lost as a technique across the Iberian peninsula by the sixth century, and was only reintroduced in the Islamic period.

$5^{6}$ Vigil-Escalera, "Aldeas altomedievales," 334-335. A caveat should be introduced here, as many contexts are dated by the pottery associated with them, and in turn, the typologies are regularly established by the finds of pots in excavated contexts. The dating is thus to a certain extent circular (pots date contexts, which date other pots), and until scientific dating is made of some of these pots, chronologies will remain rather vague.

Jorge de Juan Ares, Mari Mar Gallego García and Javier García Gómez, "La cultura mate- 
This economic and political integration of the village networks within the Visigothic administrative system impacted the social structure and the selfrepresentation of village rural elites. The disappearance of furnished burials by the end of the sixth century suggests that elites had become fixed. The need to compete for status through lavish funeral displays had disappeared. Other ways of displaying rank emerged, probably linked to the integration of these elites in the taxation system, as the slate from Gózquez may indicate. The high number of horse bones and the presence of horseshoes indicate horse-breeding in Gózquez and Navalvillar, which could be another elite identifier. ${ }^{58}$

Processes of Visigothic state formation modified the evolvement of rural communities reintroducing them into a state system. The emergence of a new elite and the reintegration of cities with their rural hinterland had a direct impact on the materiality of the village communities. It also introduced new types of rural settlement (hillforts and monasteries). This newly formed system also had its weaknesses as became evident during the political crises of the seventh century.

Resilience and Continuities into the Eighth Century

After Swinthila (r. 621-631) was deposed by a group of conspiring nobles the political stability of the Visigothic kingdom plummeted. Even if this coup was sanctioned by the Sixth Council of Toledo, in what was meant to be the start of a period of renewed stability, it only led to a period of uprisings and civil wars continuing into the eighth century and culminating with the Umayyad invasion of 711. Once the monarchy had moved from a military elite of Visigoths to an integrated land-based kingdom it became easier for parties to play kingmaker.

The political instability continued throughout most of the seventh century with usurpations and civil wars continuing until the 66os. The devaluation of the Gothic coinage, as evident from the constant decline of gold content points to the state's difficulties to extract sufficient resources or taxes. ${ }^{59} \mathrm{In}$ fact,

rial de la Vega Baja," in La Vega Baja de Toledo, ed. María del Mar Gallego García (Toledo: Toletum Visigodo, 2009), 115-147; Olmo Enciso, "Recópolis."

$5^{8} \quad$ Abad Castro, "Navalvillar," 395; Quirós Castillo and Vigil-Escalera, "Peasant Villages."

59 Jesús Vico Monteolivo, María Cruz Cores Gomendio and Gonzalo Cores Uria, Corpus Nummorum Visigothorum ca. 575-714: Leovigildus - Achila (Madrid: Vico, Cores and Cores, 2006), 99-105; Ruth Pliego Vázquez, La moneda visigoda I: Historia monetaria del Reino visigodo de Toledo (c. 569-711) (Seville: Universidad de Sevilla, 2009). 
the only reason why the state apparatus worked in its formative period may be linked to the direct inflow of cash through war booty rather than a wellfunctioning taxation system.

In urban contexts we witness a period of stagnation without new large public buildings being erected in striking contrast to the previous period. Church construction continued, however, more or less at the same paste. Other changes highlighting the decline of Roman urbanism are obvious as well. At Reccopolis the newly-laid streets were encroached on by private buildings during the seventh century. ${ }^{60}$ Complutum was hardly a nucleated urban site as most public buildings were largely in ruins and the settlement had extended far away from the old nucleus losing its physical markers of an urban site. ${ }^{61}$ The alleged renovation of the walls of Toledo were recorded in the now-lost inscription in Latin hexameters of king Wamba (r. 672-68o). ${ }^{62}$

After the deposition of Wamba in 680 another period of political strife ensued. Two main royal factions emerged, which fought for the crown up to 711, when the Visigothic kingdom was invaded by the Umayyads. Natural disasters, locusts, draughts, the plague, contributed to the effects of the crisis. The Umayyad conquest faced little local resistance once the Gothic army was defeated. ${ }^{63}$ Various factors can explain this. First, the conquerors brought a new coinage of better quality than the Gothic one. ${ }^{64}$ Moreover, the original Berber troops were largely Romanised Latin-speaking peoples who were not that different from the people living in the Peninsula. ${ }^{65}$ Finally, the conquerors' treaties, known as sulh, offered attractive conditions. ${ }^{66}$ Toledo and, probably,

6o Álvaro Sanz Paratcha, "Vida después de la muerte: los contextos cerámicos de Recópolis en época emiral," in Recópolisy la ciudad en la época visigoda, ed. Lauro Olmo Enciso, Zona Arqueológica 9 (Alcalá de Henares: Museo Arqueológico Regional, 2008), 165-179.

61 Rascón Marqués, "La ciudad de Complutum," 6o-61.

62 As preserved in Continuatio Hispanica 35, in Chronica Minora, v. 2, Monumenta Germaniae Historica Auctores Antiquissimi, v. 11, ed. Theodor Mommsen (Berlin: Preussiche Akademie, 1934, 323-369): Erexit, fautore Deo, rex inclytus urbem/Wamba, suae celebrem protendens gentis honorem./Vos, sancti Domini, quorum hic praesentia fulget/ hanc urbem et plebem solito servate favore - With God as patron, erected the city the famous king/ Wamba, to increase the honour (and) fame of his people./You, holy Masters (i.e. Saints), whose presence shines here/ serve this city and (its) people with your customary favour.

63 Pedro Chalmeta Gedrón, Invasión e islamización: la sumisión de Hispania y la formación de Al-Ándalus (Madrid: MAPRFE 1994), 68-72.

64 Eduardo Manzano Moreno, Conquistadores, emires y califas: Los Omeyas y la formación de Al-Ándalus (Barcelona: Crítica, 2006), 61-63.

65 Eduardo Manzano Moreno, "Beréberes de al-Ándalus: los factores de una evolución histórica," Al-Qantara 11, no. 2 (1990): 399-406.

66 Or so we can reconstruct from later sources (cf. Nicola Clarke, The Muslim Conquest of Iberia: Medieval Arabic Narratives (Abingdon: Routledge, 2012)). The problem is that all these sources are two centuries later than the conquest and we only have one example of 
Reccopolis surrendered by treaty which preserved the city-countryside network as these treaties allowed the original owners to keep their properties in exchange for an extra tax.

The fact that the new Umayyad administration was centred in Córdoba rather than Toledo does not seem to have affected the urban or rural network much. From the seventh century and into the mid-eighth the only remarkable changes in the villages seem to have been an shift to generational occupation. Each family dwelling was built to last 25-30 years after which it was pulled down and rebuilt at some distance. ${ }^{67}$ There does not seem to be much largescale and complete destruction and abandonment of sites at this time. The settlement linked to the old villa at El Pelícano seems to have been completely abandoned during the seventh century. ${ }^{68}$ Navalvillar was abandoned during the Islamic conquest. ${ }^{69}$ The seventh century saw on the other hand some new villages emerge such as La Huelga, Frontera de Portugal and La Charca all located at the banks of the Jarama river. ${ }^{70}$ Even burial practices continued unchanged into the eighth century. ${ }^{71}$ The only clear change in the rural landscape that can be connected to the conquest is the maqbara, Islamic cemetery, at the site of La Huelga. ${ }^{72}$ The lack of direct influences underlines the limited number of Muslims settled in the countryside at the early stages of the conquest.

As was discussed above, the rural system with its specific settlement pattern, social structure, economic production, and urban integration, which had emerged from the implosion of the villa system was strengthened and structured by the Visigothic state. Interaction between new and old elites accompanied by a re-definition of roles and ranks resulted in a cohesive and stable system which survived the collapse of the kingdom. This was corroborated by

such a treaty. It is only an assumption that these treaties were common and that were all similar.

67 Alfonso Vigil-Escalera, "Primeros pasos hacia el análisis de la organización interna de los asentamientos rurales en época visigoda," in La investigación arqueológica de la época visigoda en la Comunidad de Madrid, ed. Jorge Morín de Pablos, Zona Arqueológica 8 (Alcalá de Henares: Museo Arqueológico Regional, 2007), 371; cf. the aforementioned case of Mucking, and the 'mid-Saxon shift'.

68 Vigil-Escalera, "Aldeas altomedievales," 326.

69 Abad, "Navalvillar," 398.

70 Vigil-Escalera, "Aldeas altomedievales," 334; Sánchez Sánchez-Moreno, Galindo San José, Lorenzo and Recio Martín, "Trabajos arqueológicos," 449-453.

71 Vigil-Escalera, "El modelo de poblamiento," 9o.

72 Miguel Rodríguez Cifuentes and Luis Ángel de Juana García, "La Huelga y El Malecón: dos asentamientos altomedievales entre la tradición y el cambio," in La investigación arqueológica de la época visigoda en la Comunidad de Madrid, ed. Jorge Morín de Pablos, Zona Arqueológica 8 (Alcalá de Henares: Museo Arqueológico Regional, 2007), 418-431. 
the fact that the first generation of Muslim conquerors did not actively change much. After the 740s and 75os, however, this system would slowly come to an end.

The early years of Muslim domination over the Peninsula constituted a prolonged epilogue to the Visigothic rural network centred around Toledo. Change came when the Umayyad state eventually imposed its own system. The mideighth century was characterised by uprisings and civil wars amongst the conquerors, at first without involving the local populations, and dynastic struggles. Its main consequence was the creation of a new state independent from the control of the caliphs in Bagdad: the emirate of Córdoba. As the Goths had done in the sixth century, this new state in turn prompted a reorganisation of the territorial administration which deeply affected the village network. The vast majority of sites known from the Visigothic period were abandoned at this stage. This was for example the case in Gózquez, Melque, Patones, La Vega, Frontera de Portugal, El Pelícano, and many others. ${ }^{73}$

The Berber revolt (740-743) was the result of several latent conflicts amongst the conquerors. Several factors, including ethnic feuds between Berbers and Arabs, an unequal distribution of land with the Arabs occupying the most fertile arable land as opposed to the Berbers who had been given the most barren areas, and power struggles with Arabs dominating Berbers had already caused much enmity between the two groups. Open conflict began in 740 when extra taxes were levied on the Berbers. The rebellion began in North Africa and soon spread into the Iberian Peninsula. ${ }^{74}$ The governors of al-Andalus called for extra troops and the caliph soon sent Syrian Umayyad soldiers. These troops helped suppress the revolts, but also introduced yet another ethnic group to the Iberian melting pot. They would soon play a crucial role.

It is in this period too that the rebellious Asturians formed their kingdom in the north. King Alfonso I (r. 739-755) was instrumental as he began a series of attacks on the weakened emirate. On top of this, in 750 the Abbasids organised a coup against the Umayyads in Damascus. The only surviving member of the Umayyad house, 'Abd al-Raḥmān (r. 754-788), escaped fleeing to al-Andalus

73 Vigil-Escalera, "Aldeas altomedievales," 327, 329; Rodríguez and De Juana García, "La Huelga y El Malecón," 421-428; Alfaro Arregui and Martín Bañón, "La Vega," 417; López Quiroga, “¿Dónde vivían los germanos?” 343-344.

74 Manzano Moreno, Conquistadores, 92-101. 
where there were plenty of loyal Syrian troops. From 750 onwards, internal divisions, ethnic feuds, Christian attacks and dynastic rivalries added further instability. Civil war between Abbasid and Umayyad partisans ended in 754, when 'Abd al-Raḥmān proclaimed himself independent emir of Córdoba. Christian, usually referred to as 'Mozarab' rebellions, however, continued during his reign as did occasional pro-Abbasid revolts. ${ }^{75}$

One of the first consequences of this period of unrest was that most of the towns in the Duero basin (north of the Madrid mountains) and other enclaves south of the Pyrenees were deserted by the Berber garrisons. ${ }^{76}$ These cities had already been in steep decline during Late Antiquity, but once the Berber troops left the whole administrative infrastructure of the basin disappeared. As the Berber troops fled, an unorganised no-man's-land buffer zone was created between the Christian kingdoms of the north and al-Andalus, turning the territories of Toledo and Reccopolis from the core into $a$ frontier zone.

This led to a reorganisation of the area into a frontier march. ${ }^{77} \mathrm{Abd}$ alRaḥmān I turned Toledo into a border district whereby the city's hinterland became a militarised buffer zone. The city itself suffered very important changes during the ninth century. The Visigothic royal suburb was destroyed and besieged repeatedly and the emirs were forced to move all administrative buildings into the new citadel or almudayna. ${ }^{78}$ From this moment on, the territory was controlled from militarised fortified settlements and no longer from towns. The old town of Complutum was soon substituted as an administrative centre by a new fortified ( qal'a) settlement three kilometres away, Qal'at 'Abd al-Salām. ${ }^{79}$ In the mid-eighth century a new garrison of Syrian troops was settled next to Reccopolis at Zorita about 1.5 kilometres from the Visigothic site. ${ }^{80}$ Another fortified enclave was formed at Talamanca and later ones would develop in Guadalajara, Madrid, and Calatalifa. ${ }^{81}$ These became the main sec-

75 Manzano Moreno, Conquistadores, 105, 249.

76 Manuela Cruz Hernández, "The Social Structure of al-Andalus during the Muslim Occupation (711-755) and the Founding of the Umayyad Monarchy," in The Formation of AlAndalus, part 1: History and Society, ed. Miguel Martín (London: Aldershot, 1998), 51-85. Explained in detail with a general overview of the new settlement patterns in Eduardo Manzano Moreno, "De Hispania a Al-Andalus: la transformación de los espacios rurales y urbanos," in Città e campagna nei secoli altomedievale: Sopleto, 27 marzo-1 aprile 2008 (Spoleto: Centro di Studi sull'alto Medioevo, 2009), 473-494.

78 Antonio Almagro, "Planimetría de ciudades hispanomusulmanas," Al-Qantara 8 (1987): 432; Basilio Pavón, Ciudades hispanomusulmanas (Madrid: MAPFRE, 1992), 284; Izquierdo, "La Urbs Regia."

79 Pavón, Ciudades, 155, 157, 179.

8o Sanz Paratcha, "Vida después de la muerte," 166-173.

81 Vigil-Escalera, "El modelo de poblamiento," 98. 
ondary sites of the region, substituting the sierra enclaves. Some places such as Cancho del Confesionario show continued activity into the early Islamic period before it was fully substituted by the new foundations. ${ }^{82}$

These new centres of power substituted the old Visigothic nuclei as the main nodes of the rural network, which had already begun to crumble probably after the Berber rebellion. A new Islamic military elite controlled the largely Mozarab local population. ${ }^{83} \mathrm{~A}$ handful of sites, amongst which Prado de los Galápagos, La Indiana, continued to be inhabited into the eighth and ninth centuries without the incentive or support of the Gothic capitals and elites. ${ }^{84}$ Most of the network, however, had disappeared or was dispersed into smaller settlements which are archaeologically invisible. ${ }^{85}$ The decline in the number of silos per site during the eighth century - they nearly halved in La Indiana - confirms that the Visigothic capitals were of key importance for the existence of the rural commercial network. ${ }^{86}$ The rural population may well have moved to new villages (alquerías) linked to the new settlement patterns as they did elsewhere in the Peninsula. However, this is not visible at this time in the archaeological record in the Madrid area. This may be because most of these early alquerías have been continuously inhabited ever since and are the origins of most of the current towns of the province of Madrid. ${ }^{87}$

The political and economic focus had moved south towards Córdoba and the Madrid region had turned into a frontier zone constantly under threat. This situation probably caused the end of most of these local sites which could not prosper without the support of the Gothic capitals just like the villas declined when the Roman state and its associated economic and social structure disappeared from this region.

82 Colmenarejo García and Rovira Duque, "Los yacimientos arqueológicos de Colmenar Viejo," 381 .

83 In many areas of the Peninsula, the local elites converted to Islam, (referred to as muwalladūn). This however does not seem to have been the case of this area, due to the lack of Islamic cemeteries (maqābir) and the strong presence of urban Mozarabic communities in Toledo (Cf. Manzano Moreno, Conquistadores, 50-51).

84 Sánchez Sánchez-Moreno, Galindo San José, Lorenzo and Recio Martín, "Trabajos arqueológicos"; Vigil-Escalera, "La Indiana."

85 Colmenarejo García and Rovira Duque, "Yacimientos arqueológicos," 381.

86 Vigil-Escalera, "La Indiana," 207-208, Rodríguez Cifuentes and De Juana García, "La Huelga y El Malecón," 420.

87 López Quiroga, “¿Dónde vivían los germanos?” 352. 


\section{Conclusions}

The political development of the central Iberian Peninsula had a great impact on the evolution of its rural settlements. We should keep in mind, however, that this cannot be extrapolated to other regions of the Peninsula due to the particular political importance of this area. ${ }^{88}$ As long as there was peace and stability rural settlements survived but in times of crisis they suffered.

The organisation and means of control of the territory also fluctuated according to the ruling power of the moment. Until the Roman dominion ceased to be effective, the territory was structured and controlled by rural elites living in villas. Once the Roman economic and administrative system in which villas played a key role collapsed, the villas were soon abandoned and ceased to exist. New types of settlements emerged during the post-Roman period. This was the result of the end of the villa system and of the dissolution of Roman administration and taxation structures. New settlement patterns and building techniques gave way to the emergence of true villages and village communities in which no traces of the old Roman rural elites are identifiable, but which formed a network that supplied the Visigothic capitals of Toledo and Reccopolis. A new elite emerged out of the Gothic and Roman aristocrats serving the recently created kingdom. Their position was not based on land they owned as in the Roman period, but by the offices they held. This pattern of the rise of a state service elite perhaps finds its parallels elsewhere in the Mediterranean. The making of alliances and re-negotiation of power structures between newly established political powers and pre-existing elite circles as occurred in the Gothic-Roman establishment in the Iberian Peninsula was but one possible outcome. Across this volume other solutions to this problematic sometimes different, but many times similar can be seen in the broader late antique Mediterranean.

This network was so closely linked to these capitals and the state structures implemented there that it managed to survive the crisis of the seventh century. However, this link was so vital that once the political and economic power was removed from the cities after the civil wars and Muslim invasion of the eighth century the network collapsed. Of crucial importance was the establishment of the Umayyad emirate in Cordoba and the consequent reduction of the whole territory from core to frontier. This is especially true for the province of Madrid, where small fortified enclaves became more important than towns and villages.

88 Compare this region with other more 'marginal' areas of the Gothic kingdom, like Gallaecia, Catalonia or the Duero basin; cf. Quirós Castillo, "Early Medieval Villages." 
This does not mean that there were no rural settlements, but rather that the number of settlements dropped, while no new eighth-century settlements have been yet found.

As for the authority over this newly-organised territory, the old RomanoGothic elites were completely replaced by the new military elite active on the Islamic frontier. Again, the substitution of elite establishments and the consequent ways these controlled effectively the countryside were numerous. In the Iberian Peninsula where the arriving troops were few and confronted by a larger, albeit more poorly structured, local establishment the presented dialectics prompted the creation of new settlement patterns. Across the early Islamic and post-Roman Mediterranean we have, however, many different points of comparison.

\section{Bibliography}

\section{Primary Sources}

Continuatio Hispanica, edited by Theodor Mommsen, Chronica Minora, v. 2, Monumenta Germaniae Historica Auctores Antiquissimi, v. 11 (Berlin: Preussiche Akademie 1934, 323-369), translated by Kenneth Wolf, Conquerors and Chroniclers of Early Medieval Spain. Second Edition (Liverpool: Liverpool University Press, 1999).

Councils of Toledo, edited by Juan Vives, Concilios visigóticos e hispano-romanos (Barcelona: CSIC, 1963).

Hydatius (d. 469). "Chronica subita." In The Chronicle of Hydatius and the Consularia Constantinopolitana, edited by Richard Burgess, 69-124. Oxford: Clarendon, 1993.

John of Biclar (d. 621) Chronica a. DLXVII-DXC, edited by Theodor Mommsen, Chronica Minora, v. 2, Monumenta Germaniae Historica Auctores Antiquissimi, v. 11 (Berlin: Preussiche Akademie 1934, 207-220), translated by Kenneth Wolf, Conquerors and Chroniclers of Early Medieval Spain. Second Edition. Liverpool: Liverpool University Press, 1999.

\section{Secondary Sources}

Abad Castro, Concepción. "El poblado de Navalvillar (Colmenar Viejo)." In La investigación arqueológica de la época visigoda en la Comunidad de Madrid, edited by Jorge Morín de Pablos, 389-399. Zona Arqueológica 8. Alcalá de Henares: Museo Arqueológico Regional, 2007.

Alfaro Arregui, María del Mar, and Asunción Martín Bañón. "La Vega: un modelo de asentamiento rural visigodo en la provincial de Madrid." In La investigación arqueológica de la época visigoda en la Comunidad de Madrid, edited by Jorge Morín 
de Pablos, 403-417. Zona Arqueológica 8. Alcalá de Henares: Museo Arqueológico Regional, 2007.

Almagro, Antonio. "Planimetría de ciudades hispanomusulmanas." Al-Qantara 8, no. 1 (1987): 421-448.

Beltrán de Heredia Bercero, Julia. "Continuity and Change in the Urban Topography: Archaeological Evidence of the North-East Quadrant of the City." In From Barcino to Barcinona (first to seventh centuries): The Archaeological Remains of the Plaça del Rei in Barcelona, edited by Julia Beltrán de Heredia, 96-111. Barcelona: Museu d'Història de la Ciutat, 2002.

Beltrán de Heredia Bercero, Julia. “Barcino durante la antigüedad tardía." In Recópolis y la ciudad en la época visigoda, edited by Lauro Olmo Enciso, 274-291. Zona Arqueológica 9. Alcalá de Henares: Museo Arqueológico Regional, 2008.

Caballero Casado, Carlos. "Caminos sobre caminos: un recorrido por las rutas visigodas en Madrid." In La investigación arqueológica de la época visigoda en la Comunidad de Madrid, edited by Jorge Morín de Pablos, 92-102. Zona Arqueológica 8. Alcalá de Henares: Museo Arqueológico Regional, 2007.

Caballero Zoreda, Luis. "El conjunto monástico de Santa María del Melque (Toledo) siglos VIII-IX.” In Monjes y monasterios hispanos en la Alta Edad, edited by José Ángel García de Cortázar and Ramón Teja Ruiz de Aguirre, 99-146. Toledo: Fundación Santa María La Real, Centro de Estudios del Románico, 2006.

Chalmeta Gedrón, Pedro. Invasión e islamización: la sumisión de Hispaniay la formación de Al-Ándalus. Madrid: MAPFre, 1994.

Chrysos, Evangelos. "The Empire, the gentes and the regna." In Regna and Gentes: The Relationship between Late Antique and Early Medieval Peoples and Kingdoms in the Transformation of the Roman World, edited by Hans-Werner Goetz, Jörg Jarnut and Walter Pohl, 13-20. Leiden: Brill, 2003.

Clarke, Nicola. The Muslim Conquest of Iberia: Medieval Arabic Narratives. Abingdon: Routledge, 2012.

Colmenarejo García, Fernando and Cristina Rovira Duque. "Los yacimientos arqueológicos de Colmenar Viejo durante la Antigüedad Tardía." In La investigación arqueológica de la época visigoda en la Comunidad de Madrid, edited by Jorge Morín de Pablos, 376-382. Zona Arqueológica 8. Alcalá de Henares: Museo Arqueológico Regional, 2007.

Cruz Hernández, Manuela. "The Social Structure of al-Andalus During the Muslim Occupation (711-755) and the Founding of the Umayyad Monarchy." In The Formation of Al-Andalus, part 1: History and Society, edited by Miguel Martín, 51-85. London: Aldershot, 1998.

Fernández Delgado, Aitor, Javier Martínez Jiménez and Carlos Tejerizo García. "New and Old Elites in the Visigothic Kingdom (550-650 AD)." In Tough Times: The Archaeology of Crisis and Recovery. Proceedings of the GAO Annual Conferences 2010 and 2011, 
edited by Elsbeth van der Wilt and Javier Martínez Jiménez, 161-170. British Archaeological Reports International Series 2478. Oxford: Archaeopress, 2013.

Fernández-Galiano, Dimas. Carranque:Esplendor de la Hispania de Teodosio. Barcelona: Museu d' Arqueologia de Catalunya, 2001.

Fuentes Domínguez, Ángel. La Necrópolis tardorromana de Albalate de las Nogueras (Cuenca) y el problema de las denominadas 'Necrópolis del Duero'. Arqueología Conquense 10. Cuenca: Diputación Provincial de Cuenca, 1989.

García García, Miguel Ángel. "Sarcófagos romanos decorados del siglo IV en el territorio andaluz: enfoques y problemática vigente." Spal 21 (2012): 183-193.

García Moreno, Luis A., ed. 711: Arqueología e Historia entre dos mundos. Zona Arqueológica 15. Alcalá de Henares: Museo Arqueológico Regional, 2011.

Gurt Esparraguera, Josep Maria, and Pilar Diarte Blasco. "La basílica de santa Leocadia y el final de uso del circo romano de Toledo: una nueva interpretación." Zephyrus 69 (2012): 149-163.

Gutiérrez Lloret, Sonia, and Julia Sarabia Bautista. “The Episcopal Complex of Eio-El Tolmo de Minateda (Hellín, Albacete, Spain): Architecture and Spatial Organization." Hortus Artium Medievalium 19 (2013): 262-30o.

Hamerow, Helena. "Settlement Mobility and the 'Middle Saxon Shift': Rural Settlements and Settlement Patterns in Anglo-Saxon England." Anglo-Saxon England 20 (1991): $1-18$.

Hamerow, Helena. Early Medieval Settlements: The Archaeology of Rural Communities in Northwest Europe, 400-900. Oxford: Oxford University Press, 2002.

Halsall, Guy. Barbarian Migrations and the Roman West, 376-568. Cambridge Medieval Textbooks. Cambridge: Cambridge University Press, 2007.

Heather, Peter. The Fall of the Roman Empire: A New History of Rome and the Barbarians. Oxford: Oxford University Press, 2005.

Izquierdo Benito, Ricardo. "La Urbs Regia." In Hispania Gothorum: San Ildefonso y el reino visigodo de Toledo, edited by Rafael García Serrano, 143-159 Toledo: Toletum Visigodo, 2007 .

Juan Ares, Jorge de, Mari Mar Gallego García and Javier García Gómez. "La cultura material de la Vega Baja." In La Vega Baja de Toledo, edited by María del Mar Gallego García, 115-147. Toledo: Toletum Visigodo, 2009.

Kulikowski, Michael. "Plague in Spanish Late Antiquity." In Plague and the End of Antiquity: The Pandemic of 541-750, edited by Lester Little, 150-170. Cambridge: Cambridge University Press, 2007.

Liebeschuetz, Wolfgang. "The End of the Ancient City." In The City in Late Antiquity, edited by John Rich, 1-50. London: Routledge, 1992.

López Quiroga, Jorge. “¿Dónde vivían los germanos? Poblamiento, hábitat y mundo funerario en el occidente europeo entre los ss. vy viı. Balance historiográfico, problemas y perspectivas desde el centro del reino 'godo' de Toledo." In La investigación 
arqueológica de la época visigoda en la Comunidad de Madrid, edited by Jorge Morín de Pablos, 309-364. Zona Arqueológica 8. Alcalá de Henares: Museo Arqueológico Regional, 2007.

Manzano Moreno, Eduardo. "Beréberes de al-Ándalus: los factores de una evolución histórica." Al-Qantara 11, no. 2 (1990): 397-421.

Manzano Moreno, Eduardo. Conquistadores, emires y califas: los Omeyas y la formación de Al-Ándalus. Barcelona: Crítica, 2006.

Manzano Moreno, Eduardo. "De Hispania a Al-Andalus: la transformación de los espacios rurales y urbanos." In Città e campagna nei secoli altomedievale: Sopleto, 27 marzo-1 aprile 20o8, edited by Andrea Castagnetti, 473-494. Spoleto: Centro di Studi sull'alto Medioevo, 2009.

Martín Viso, Iñaki. “Tributación y escenarios locales en el centro de la Península Ibérica: algunas hipótesis a partir del análisis de las pizarras visigodas." Antiquité Tardive 14 (2006): 263-29o.

Martínez Jiménez, Javier. "Crisis or Crises? The End of Roman Towns in Iberia between the Late Roman and the Early Umayyad Periods." In Tough Times: The Archaeology of Crisis and Recovery. Proceedings of the GAO Annual Conferences 2010 and 2011, edited by Elsbeth van der Wilt and Javier Martínez Jiménez, 77-9o. British Archaeological Reports International Series 2478. Oxford: Archaeopress, 2013.

Martínez Jiménez, Javier. "Aqueducts and Water Supply in the Towns of Post-Roman Spain AD 400-100o." PhD diss., Oxford University, 2014.

Martínez Jiménez, Javier. "A Preliminary Study of the Aqueduct of Reccopolis." Oxford Journal of Archaeology 34, no. 3 (2015): 301-320.

Martínez Jiménez, Javier and Tejerizo García, Carlos. "Central Places in the Post-Roman Mediterranean: Regional Models for the Iberian Peninsula." Journal of Mediterranean Archaeology 28, no. 1 (2015): 105-132.

Martínez Jiménez, Javier. "Water Supply in the Visigothic Urban Foundations of Eio (El Tolmo de Minateda) and Reccopolis." In New Cities in Late Antiquity: Documents and Archaeology, edited by Efthymios Rizos, 233-246. Bibliotéque de l' Antiquité Tardive 35. Turnhout: Brepols, 2017.

Martínez Jiménez, Javier, Isaac Sastre de Diego and Carlos Tejerizo García. The Iberian Peninsula Between 300 and 850: An Archaeological Perspective. Late Antique and Early Medieval Iberia 6. Amsterdam: Amsterdam University Press, 2018.

Moreno Martín, Francisco. La arquitectura monástica hispana entre la Tardoantigüedad y la alta Edad Media. British Archaeological Reports International Series 2287. Oxford: Archaeopress, 2011.

Morín de Pablos, Jorge, Rafael Barroso Cabrera, Mario López Recio, Fernando Sánchez Hidalgo and Francisco José López Fraile. "Repertorio de yacimientos de época visigoda en la Comunidad de Madrid." In La investigación arqueológica de la época visigoda en la Comunidad de Madrid, edited by Jorge Morín de Pablos, 55-92. Zona Arqueológica 8. Alcalá de Henares: Museo Arqueológico Regional, 2006. 
Olmo Enciso, Lauro. “Recópolis: una ciudad en época de transformaciones.” In Recópolis y la ciudad en la época visigoda, edited by Lauro Olmo Enciso, 40-63. Zona Arqueológica 9. Alcalá de Henares: Museo Arqueológico Regional, 2008.

Olmo Enciso, Lauro. "La Vega Baja en época visigoda: una investigación arqueológica en construcción." In La Vega Baja de Toledo, edited by María del Mar Gallego García, 69-94. Toledo: Toletum Visigodo, 2009.

Olmo Enciso, Lauro. "Ciudad y Estado en época Visigoda: la construcción de un nuevo paisaje urbano." In Espacios urbanos en el Occidente Mediterráneo ss. VI-VIII, edited by Antonio García, Ricardo Izquierdo, Lauro Olmo and Diego Perís, 87-112. Toledo: Toletum Visigodo, 2010.

Pavón, Basilio. Ciudades hispanomusulmanas. Madrid: MAPFRE, 1992.

Pliego Vázquez, Ruth. La moneda visigoda I: Historia monetaria del Reino visigodo de Toledo (c. 569-7n). Seville: Universidad de Sevilla, 2009.

Quirós Castillo, Juan Antonio, and Alfonso Vigil-Escalera "Networks of Peasant Villages between Toledo and Velegia Alabense, Northwestern Spain ( $\mathrm{V}-\mathrm{xth}$ Centuries)." Archaeologia Medievale 33 (2006): 79-128.

Quirós Castillo, Juan Antonio. "Early Medieval Villages in Spain in the Light of European Experience: New Approaches in Peasant Archaeology." In The Archaeology or Early Medieval Villages in Europe, edited by Juan Antonio Quirós Castillo, 1328. Documentos de Arqueología e Historia 1. Bilbao: Euskal Herriko Unibersitatea, 2009 .

Rascón Marqués, Sebastián. "La ciudad de Complutum en la tardoantigüedad: restauración y renovación.” In Acta Antiqua Complutensia I: Complutim y las ciudades hispanas en la antigüedad tardía, edited by Luis García Moreno and Sebastián Rascón Marqués, 51-70. Alcalá de Henares: Universidad de Alcalá, 1999.

Rascón Marqués, Sebastián, and Ana Lucía Sánchez Montes. "Urbanismo de la ciudad de Complutum los siglos VI-VII." In Recópolis y la ciudad en la época visigoda, edited by Lauro Olmo Enciso, 243-258. Zona Arqueológica 9. Alcalá de Henares: Museo Arqueológico Regional, 2008.

Ribera Lacomba, Albert, and Miquel Rosselló Mesquida. "La ciudad de Valentia en época visigoda." In Los orígenes del cristianismo en Valencia y su entorno, edited by Albert Ribera Lacomba, 151-164. Valencia: Ajuntament de València, 2000.

Ribera Lacomba, Albert. "La ciudad de Valencia durante el periodo visigodo." In Recópolis y la ciudad en la época visigoda, edited by Lauro Olmo Enciso, 303-320. Zona Arqueológica 9. Alcalá de Henares: Museo Arqueológico Regional, 2008.

Rodríguez, Santiago, and Carlos Barrio. "Poblamiento tardorromano en el valle medio del río Guadarrama (Toledo)." Bolskan 20 (2003): 267-275.

Rodríguez Cifuentes, Miguel, and Luis Ángel de Juana García. “La Huelga y El Malecón: dos asentamientos altomedievales entre la tradición y el cambio." In La investigación arqueológica de la época visigoda en la Comunidad de Madrid, edited by Jorge Morín 
de Pablos, 418-431. Zona Arqueológica 8. Alcalá de Henares: Museo Arqueológico Regional, 2007.

Rojas Rodríguez-Malo, Juan Manuel. "Guarrazar: Arqueología y nuevos recursos: un proyecto con un siglo y medio de retraso." In vi Jornadas de Cultura Visigoda, 31$5^{2}$ Guadamur: Ayuntamiento de Guadamur, 2014.

Sánchez Sánchez-Moreno, Vicente M., Lorenzo Galindo San José and Rebeca C. Recio Martín. “Trabajos arqueológicos en el yacimiento 'El Prado de los Galápagos'” In La investigación arqueológica de la época visigoda en la Comunidad de Madrid, edited by Jorge Morín de Pablos, 447-469. Zona Arqueológica 8. Alcalá de Henares: Museo Arqueológico Regional, 2007.

Sanz Paratcha, Álvaro. "Vida después de la muerte: los contextos cerámicos de Recópolis en época emiral." In Recópolis y la ciudad en la época visigoda, edited by Lauro Olmo Enciso, 165-179. Zona Arqueológica 9. Alcalá de Henares: Museo Arqueológico Regional, 2008.

Sirks, Boudewijn. "Reconsidering the Roman Colonate." Zeitschrift der Savigny-Stiftung für Rechtsgeschichte: Romanistische Abteilung 110, no. 1 (1993): 331-369.

Tejerizo García, Carlos. "Ethnicity in Early Middle Age Cemeteries: The Case of the "Visigothic" Burials." Arqueología y Territorio Medieval 18 (2011): 29-43.

Tejerizo García, Carlos. "Estructuras de fondo rehundido altomedievales en la Península Ibérica." Munibe 65 (2014): 215-237.

Thompson, Edward. Los Godos en España. Madrid: Alianza, 2007.

Valero Tévar, Miguel Ángel. “La villa romana de Noheda: la sala triclinar y los mosaicos.” PhD diss., University of Castilla-La Mancha, 2015.

Vico Monteolivo, Jesús, María Cruz Cores Gomendio and Gonzalo Cores Uria. Corpus Nummorum Visigothorum ca. 575-714: Leovigildus - Achila. Madrid: Vico, Cores and Cores, 2006.

Vigil-Escalera Girado, Alfonso. "La Indiana (Pinto, Madrid): Estructuras de habitación, almacenamiento, hidráulicas y sepulcrales de los ss. VI-IX en la Marca Media." XXIV Congreso Nacional de Arqueología 5 (1999): 205-212.

Vigil-Escalera Girado, Alfonso. "Cabañas de época visigoda: evidencias arqueológicas del sur de Madrid: Tipología, elementos de datación y discusión." Archivo Español de Arqueología 73 (2000): 223-252.

Vigil-Escalera Girado, Alfonso. "El modelo de poblamiento rural en la meseta y algunas cuestiones de visibilidad arqueológica." In Gallia e Hispania en el contexto de la presencia 'germánica' (ss. V-VII). Balance y perspectivas, edited by Jorge López Quiroga, Artemio Manuel Martínez Tejeda and Jorge Morín de Pablos, 89-108. British Archaeological Reports International Series 1534. Oxford: Archaeopress, 2006.

Vigil-Escalera Girado, Alfonso. "Primeros pasos hacia el análisis de la organización interna de los asentamientos rurales en época visigoda." In La investigación arqueológica de la época visigoda en la Comunidad de Madrid, edited by Jorge Morín 
de Pablos, 367-372. Zona Arqueológica 8. Alcalá de Henares: Museo Arqueológico Regional, 2007.

Vigil-Escalera Girado, Alfonso. "Las aldeas altomedievales madrileñas y su proceso formativo." In The Archaeology of Early Medieval Villages in Europe, edited by Juan Antonio Quirós Castillo, 315-339. Documentos de Arqueología e Historia 1. Bilbao: Euskal Herriko Unibersitatea, 2009.

Ward-Perkins, Bryan. The Fall of Rome and the End of Civilisation. Oxford: Oxford University Press, 2005 .

Waterbolk, Harm Tjalling and Otto Harsema. "Medieval Farmsteads in Gasselte." Palaeohistoria 21 (1979): 228-265.

Wickham, Chris. Framing the Early Middle Ages: Europe and the Mediterranean: 40o80o. Oxford: Oxford university Press, 2005.

Wood, Jamie. and Javier Martínez Jiménez. "New Directions in the Study of Visigothic Spain." History Compass 14, no. 1 (2016): 29-38. 